\title{
Energy Consumption Analysis of Sintering Temperature Optimization of Pure Aluminum Powder Metal Compacts Sintered by Using The UHFIS
}

\begin{tabular}{|c|c|c|}
\hline \multicolumn{3}{|c|}{ Mehmet TAŞTAN $^{1}$, Hayrettin GÖKOZAN², Pınar SARI ÇAVDAR ${ }^{3}$, Gürkan SOY ${ }^{4}$, Uğur ÇAVDAR $^{5 *}$} \\
\hline $\begin{array}{r}, 2 \text { Manisa Celal Bay } \\
{ }^{3} \text { Manisa Celal Bo } \\
{ }^{4,5} \text { Manisa Celal }\end{array}$ & $\begin{array}{l}\text { ersity, Turgutlu Vocational Sch } \\
\text { iversity, Turgutlu Vocational Sc } \\
\text { University, Turgutlu Vocational }\end{array}$ & $\begin{array}{l}\text { epartment of Electric \& Energy } \\
\text { Department of Construction } \\
\text {, Department of Machinery }\end{array}$ \\
\hline Başvuru/Received: 08/10/2017 & Kabul/Accepted: 01/12/2017 & Son Versiyon/Final Version: $26 / 12 / 2017$ \\
\hline
\end{tabular}

\begin{abstract}
In this study, pure aluminum ( $\mathrm{Al})$ powder metal $(\mathrm{PM})$ compacts are sintered conventional or induction systems. PM compacts are sintered by furnace at $600^{\circ} \mathrm{C}$ in 60 minutes in the conventional sintering process. In the other process, PM compacts are sintered by induction system at seven different sintering temperatures from $550 \square \mathrm{C}$ to $610 \square \mathrm{C}$ in 4 minutes. $2.8 \mathrm{~kW}, 900 \mathrm{kHz}$ ultra-high frequency induction system (UHFIS) used for heating application of induction sintering process. Densities and hardness values are investigated for both processes. During these sintering processes, all energy consumption results are measured and calculated, then compared with each other. The effects of the sintering time increase in the induction sintering process on energy cost have been analyzed. Optimum sintering temperature of the induction sintering process is determined. It has been seen that the cheaper energy cost is obtained by the induction system for sintering application.
\end{abstract}

\section{Key Words}

“Aluminum, PM, Induction, Energy cost, Energy consumption." 


\section{Introduction}

Powder metallurgy (PM) (Amirjan et al., 2013), (Sedlak et al., 2015) is a form of production, which facilitates the manufacture of particularly complex parts, made by mixing pure or alloyed powders of suitable specifications with a mixer, compressing them in a suitable mold with the desired shape to be mixed, and heating them to a temperature below the melting temperature (Angelo,2008).

Sintering (Pozzoli et al., 2015), (Caliman et al.,2015) is the most important production process of powder metallurgy. It is the process of increasing the grain size of the powder particles by increasing the strength of the particles and the strength of the powder components by heating them at a temperature below the melting temperature (Kang,2004).

PM based compacts are sintered by atmosphere controlled furnace, ultra-high frequency induction system (UHFIS) (Çavdar,2014), (Xun et al., 2014), (Gökozan et al.,2016), (Çavdar \& Çavdar, 2015).

Induction system could be using different processes like; forging (Çavdar, 2015), heat treatment (Taştan et al.,2015), welding (Çavdar \& Kusoglu, 2014), (Çavdar \& Gulsahin, 2014) or casting. Also PM based compacts are sintered by microwave sintering (Baghani et al., 2015), (Reddy et al., 2016) spark plasma sintering (Mackie et al., 2016), (Dutel et al., 2017), laser sintering (Wudy et al., 2016), (Yasa et al., 2016) and conventional Sintering (Sharma \& Majumdar, 2016), (Lemke et al., 2017)

In the study of Bisht et al (Bist et al., 2017) Al-GNP alloy (Graphene nanoplatelets) was sintered at $550^{\circ} \mathrm{C}$ for $40 \mathrm{~min}$. In the study of Guo et al (Guo et al., 2017) Al-CNTs alloy (carbon nanotubes (CNTs) were sintered at 590-630 ${ }^{\circ} \mathrm{C}$ for 30 min under argon. In the study of Ghasali et al (Ghasali et al., 2016) Al-VC (vanadium carbide) alloy was sintered by conventional sputter plasma sintering at $600^{\circ} \mathrm{C}$ for 60 minutes at $600{ }^{\circ} \mathrm{C}$ and at $450^{\circ} \mathrm{C}$ for 60 minutes. In the study of Cooke et al (Cooke et al., 2016) Al-Sc alloy was sintered at $400,450,500$ or $550^{\circ} \mathrm{C}$ for $2 \mathrm{~min}$. In the study of Durowoju et al (Durowoju et al., 2015) Gr$\mathrm{Al}$ (graphite aluminum) alloy was sintered at 500,550 and $580^{\circ} \mathrm{C}$ for $10 \mathrm{~min}$. In the study of Firestein et al (Firestein et al., 2017) aluminum-based BN, AlB2 and AlN doped alloys were sintered at $600^{\circ} \mathrm{C}$ for $60 \mathrm{~min}$. In the study of Sweet et al (Sweet et al., 2014) in commercial purity and $0.4 \mathrm{wt} \%$ magnesium-doped aluminum powders were sintered at $400-600^{\circ} \mathrm{C}$ for $30 \mathrm{~s}, 120 \mathrm{~s}$, and 300s.

Taskin and Gokozan (Taskin\&Gokozan, 2011) used current and voltage data from a three-phase induction motor.In their work, Ozdemir and Tastan (Özdemir\&Taştan, 2014) used the power furnace of the arc furnace used in metal melting processes in the industry using the LabVIEW based measurement system used in this study.

In this study, pure Al PM samples were sintered using conventional method or induction. The results obtained are compared among themselves and the optimum sintering temperature is found by induction. In addition, energy consumption and energy cost analysis were performed as a result of induction and conventional sintering of Al PM samples.

\section{Materials and Methods}

In the study, pure Al PM samples were separated into 2 different groups, some sintered in batch type furnace and the other part in induction system. The image of the induction system used in the sintering process is given in Figure 1.

In order to obtain a homogeneous mixture, $\mathrm{Al}$ powders were mixed with a $\mathrm{V}$-type mixer at $20 \mathrm{rpm}$ for 30 minutes and then produced by single-axis single-acting hydropar press with $300 \mathrm{MPa}$ cold pressing method. The resulting PM compacts have a diameter of $18 \mathrm{~mm}$ and a height of $2 \mathrm{~mm}$. The sizes of the aluminum powders are $45-106 \mu \mathrm{m}$. 


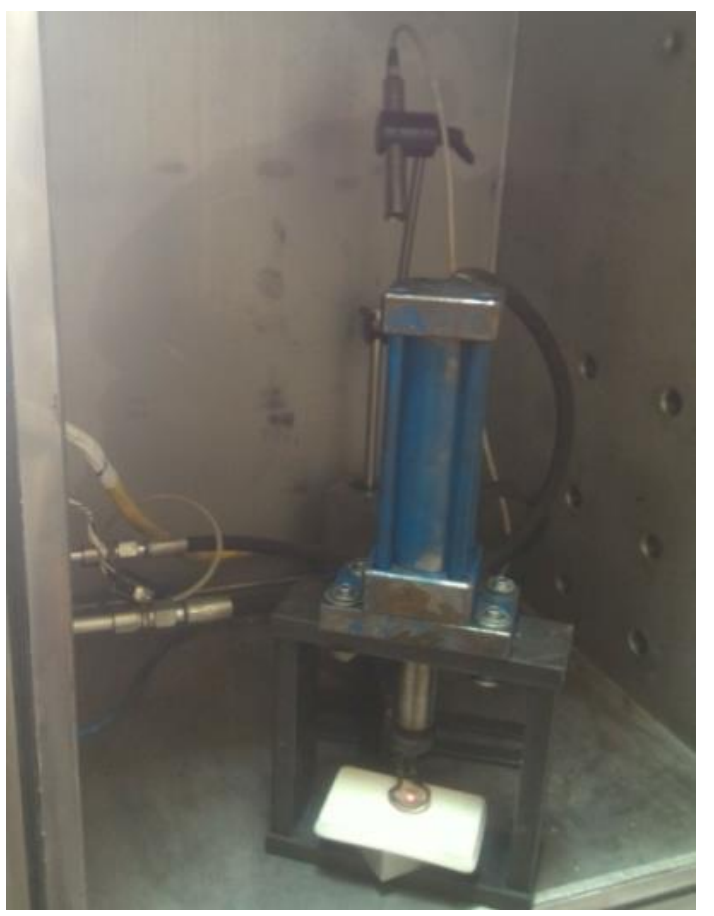

Figure 1: Image of induction system

The first group of samples was sintered using an induction system with a $900 \mathrm{kHz}$ ultra-high frequency and a power of $2.8 \mathrm{~kW}$. The induction temperature is measured and controlled without contact with the infrared thermometer in the system. Al PM compacts were sintered with UHFIS aid at 7 different temperatures between $550-610^{\circ} \mathrm{C}$ for 4 minutes dwell time in $10^{-1}$ thoor vacuum environment. PM compacts are cooled naturally.

The image of the sample for the induction sintering is given in Figure 2. Sintered images of the sample at three different sintering temperatures with induction are given in Figure 3.

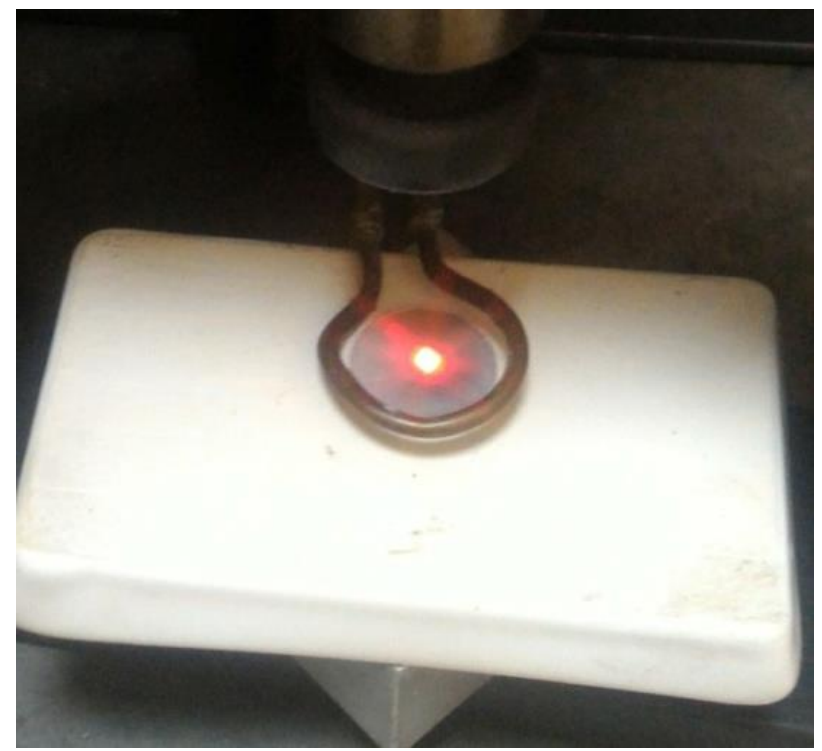

Figure 2 (a) 


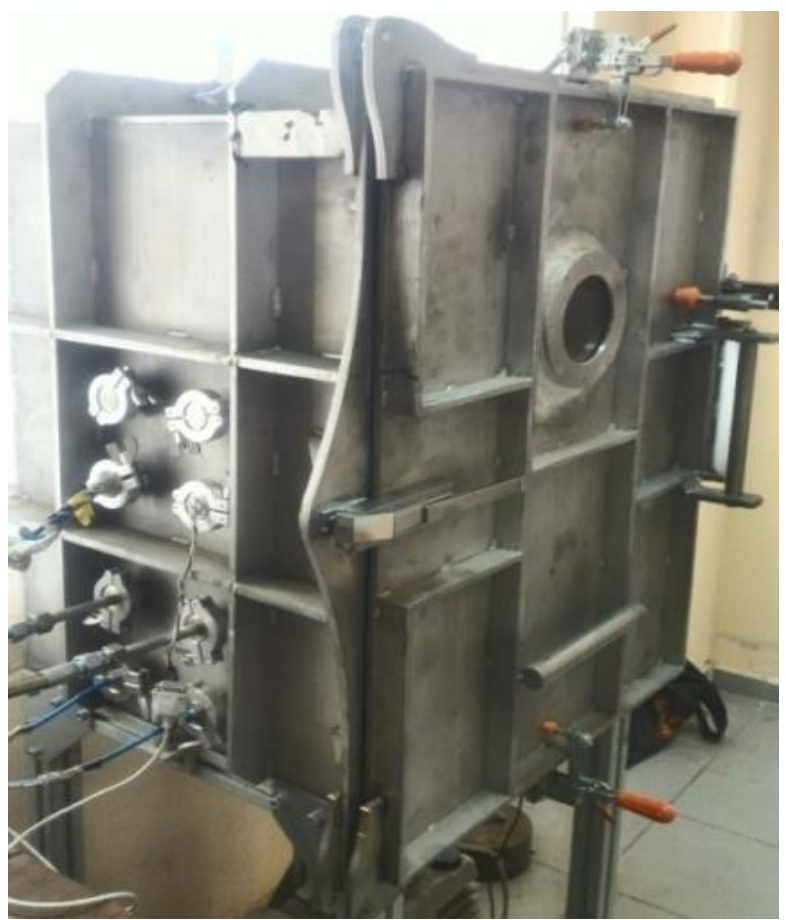

(b)

Figure 2(Cont) a) Induction sintering process b) Sintering in a vacuum environment

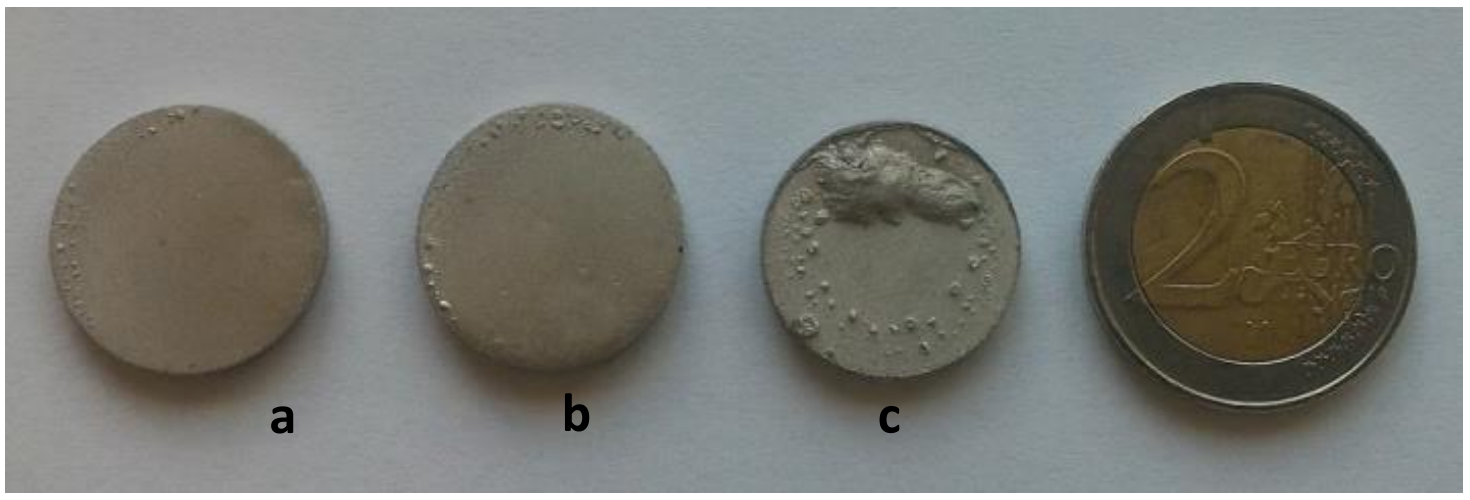

Figure 3: a) $550^{\circ} \mathrm{C} \mathrm{b)} 600^{\circ} \mathrm{C}$ c) $610^{\circ} \mathrm{C}$ specimens sintered by induction.

The second group of samples was sintered in an open atmosphere at $600^{\circ} \mathrm{C}$ for 60 minutes using Proterm brand Chember Furnace at $2 \mathrm{~kW}$ power. PM compacts are cooled naturally. Figure 4-a shows the sintered Al PM sample in the furnace. All the operations of the presented work are given in Figure 5. 


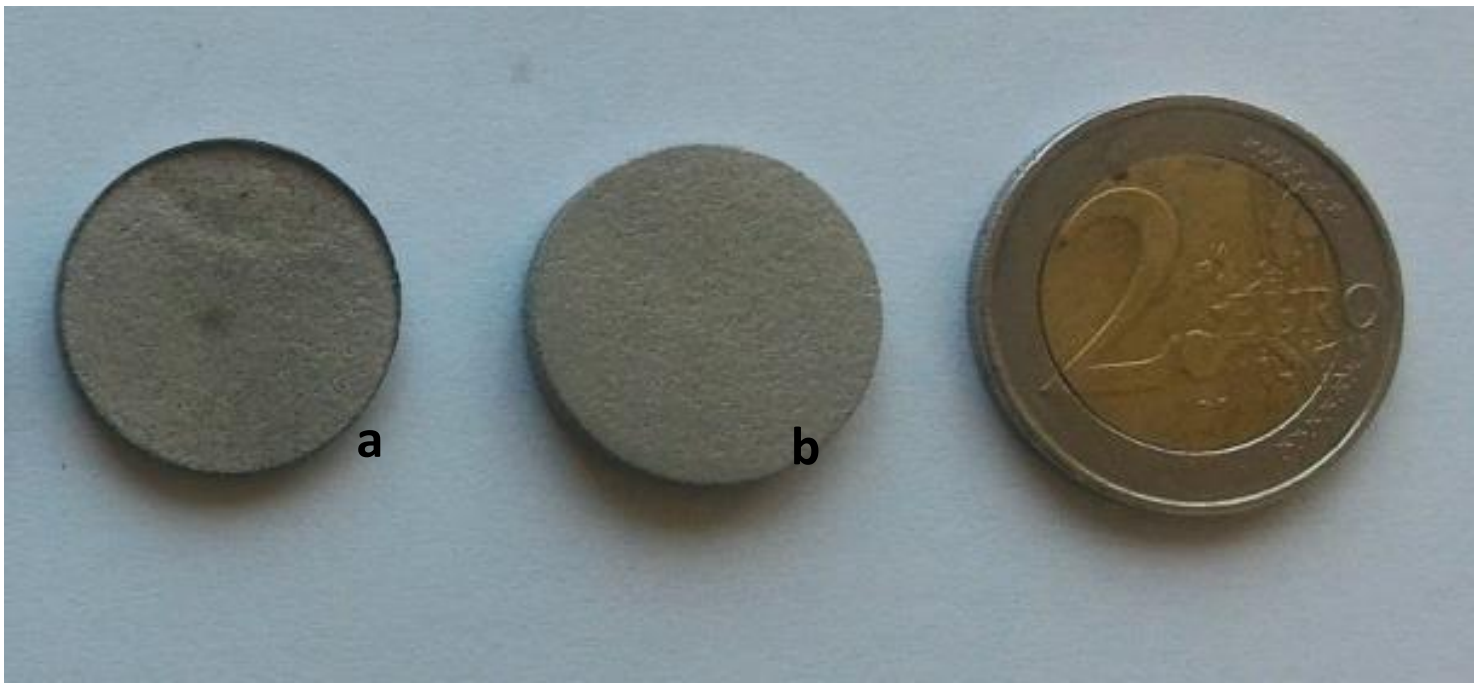

Figure 4: a) Sintered Al PM sample in furnace b) Non-sintered Al PM sample

The hardness measurements of the samples were made with the TIME TH-140 Digital Hardness tester. The hardness values were taken from 5 different points of each sample and the results were found by calculating the average hardness values.

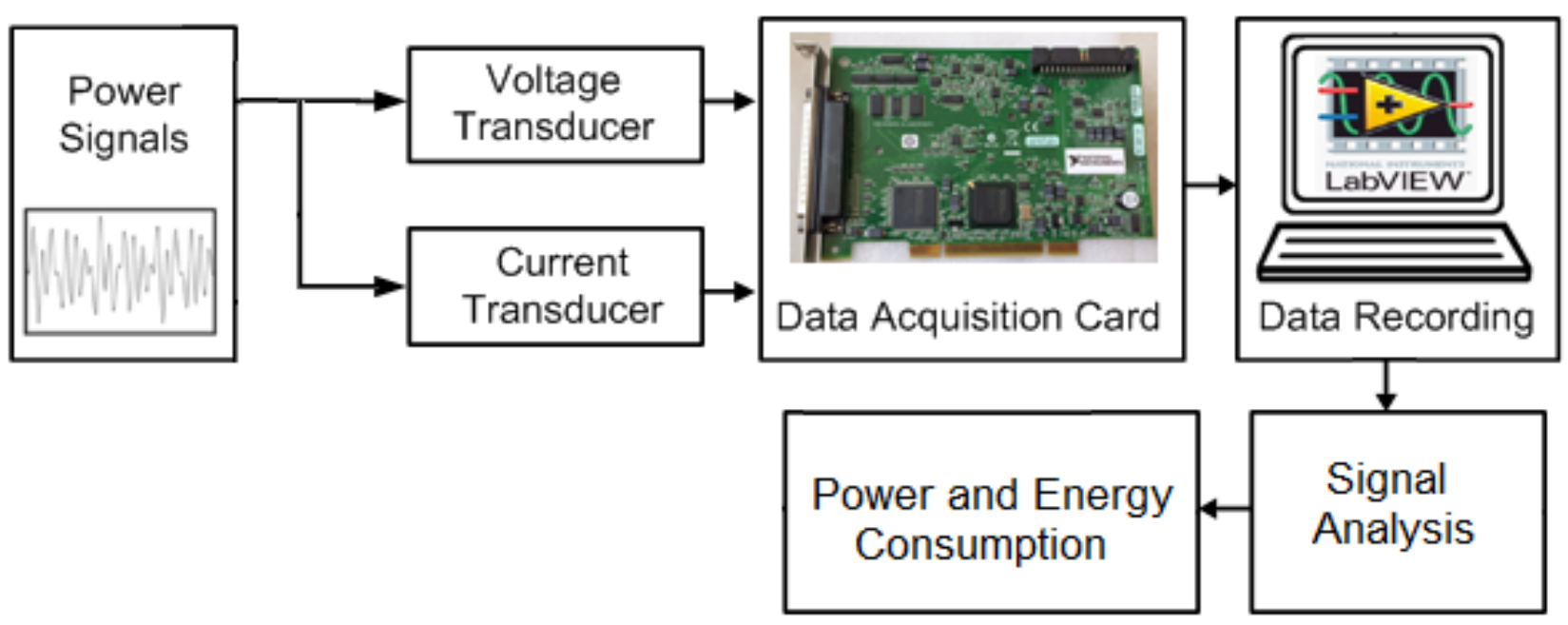

Figure 6: The block structure of the LabVIEW-based data acquisition and recording system. 


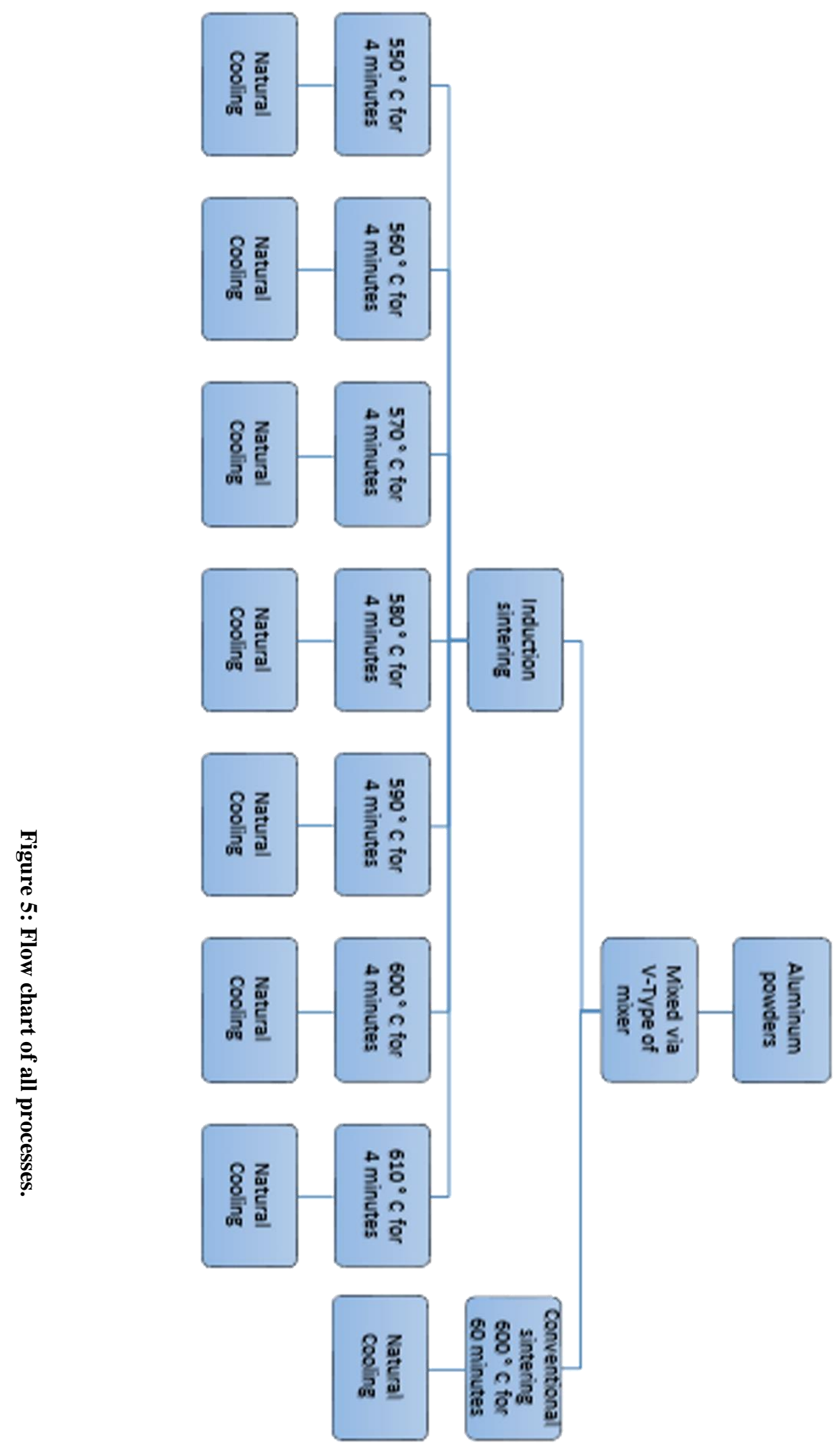


Figure 6 shows the structure of the data acquisition and recording system based on LabVIEW. Electrical data such as current, voltage, and power factor for the experimental runs were recorded with the LabVIEW 8.5 graphical interface program on a National Instruments data acquisition card in accordance with the relevant IEC standards via current and voltage sensors. By using these power parameters obtained with this data collection system, necessary power calculations (Taskin\&Gokozan,2011), (Özdemir\&Taştan, 2014) have been made.

\section{Results and Discussion}

Figure 7 shows the change of the current graph of induction sintering of $\mathrm{Al} \mathrm{PM}$ at $600^{\circ} \mathrm{C}$ for the first 20 seconds. It is seen that the current value decreases as the sample set temperature reaches about 4 seconds after sintering starts. An average current of approximately $16 \mathrm{~A}$ was drawn from the system until the sample set reached temperature. The system has continued to operate with a current of around $5 \mathrm{~A}$ after the set temperature has been reached.

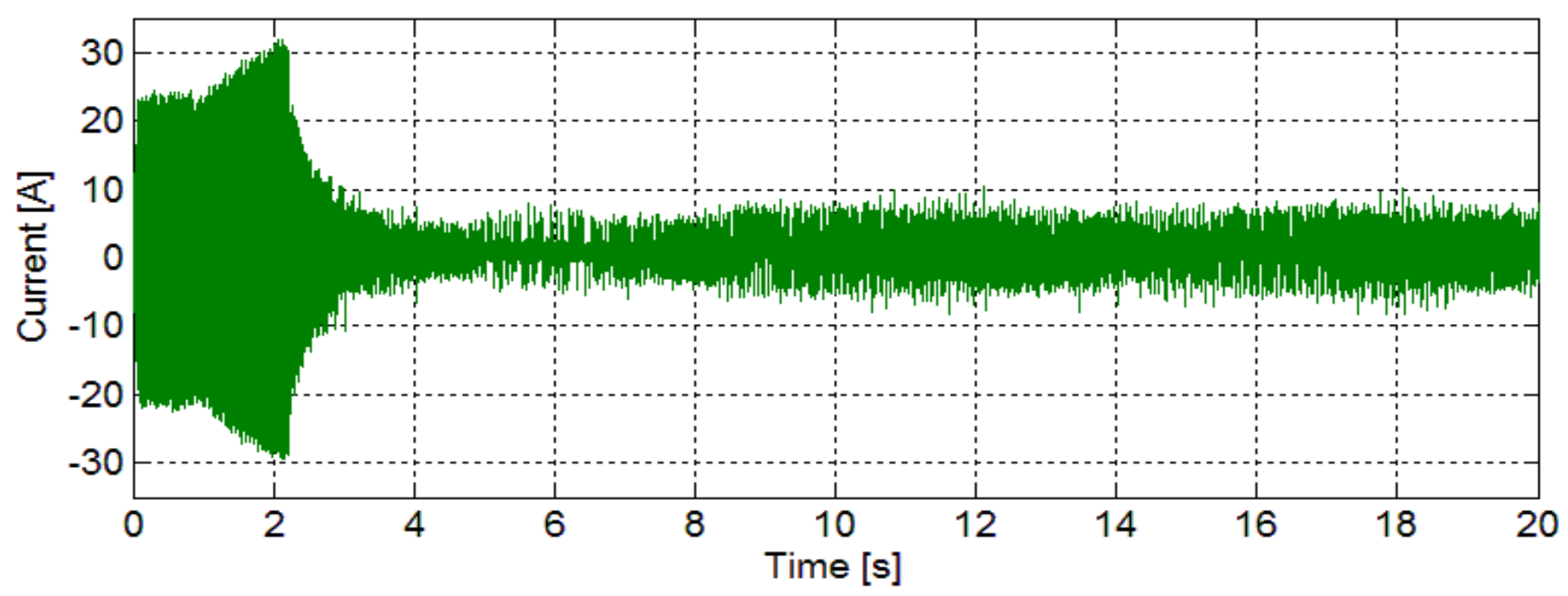

Figure 7: Current graph of the sintering process at $600^{\circ} \mathrm{C}$ temperature.

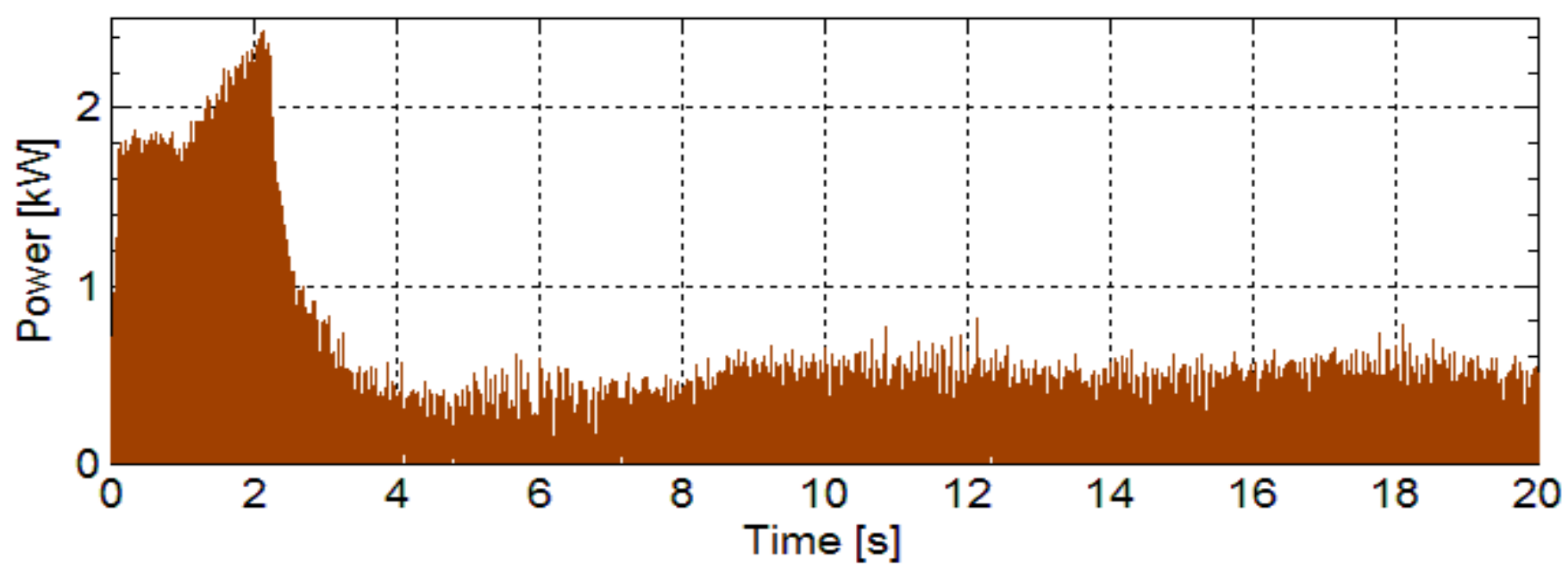

Figure 8: Power change graph of the sintering process at $600^{\circ} \mathrm{C}$ temperature.

Figure 8 shows the time-dependent power change graph of the induction sintering process of the Al PM specimen at a temperature of $600^{\circ} \mathrm{C}$. The graph shows the change of the first $20 \mathrm{~s}$. The sample reaches the set temperature within approximately $4 \mathrm{~s}$ and the 
average instantaneous power consumption during this time ranges from 1 to $1.5 \mathrm{~kW}$. After the sample reaches the set temperature, the system continues to operate with an average of 0.3-0.4 $\mathrm{kW}$ instantaneous power consumption.

Table 1: HB hardness and density values of aluminum samples

\begin{tabular}{|c|c|c|c|c|c|c|c|c|}
\hline \multirow{2}{*}{$\begin{array}{c}\text { Al PM } \\
\text { Compacts }\end{array}$} & \multicolumn{7}{|c|}{$\begin{array}{l}\text { Induction Sintering } \\
\text { (4 minutes) }\end{array}$} & \multirow{2}{*}{$\begin{array}{c}\begin{array}{c}\text { Conventional } \\
\text { Sintering }\end{array} \\
600^{\circ} \mathrm{C} \\
(60 \mathrm{~min} .)\end{array}$} \\
\hline & $550{ }^{\circ} \mathrm{C}$ & $560^{\circ} \mathrm{C}$ & $570^{\circ} \mathrm{C}$ & $580^{\circ} \mathrm{C}$ & $590{ }^{\circ} \mathrm{C}$ & $600{ }^{\circ} \mathrm{C}$ & $610^{\circ} \mathrm{C}$ & \\
\hline Hardness (HB) & 24 & 25 & 27 & 30 & 32 & 34 & 42 & 35 \\
\hline $\operatorname{Density}\left(\mathrm{g} / \mathrm{cm}^{3}\right)$ & 2,239 & 2,271 & 2,309 & 2,388 & 2,426 & 2,450 & 2,610 & 2,475 \\
\hline \% Density & 82,6 & 83,8 & 85,2 & 88,1 & 89,5 & 90,4 & 96,3 & 91,3 \\
\hline
\end{tabular}

PM The hardness and density values of aluminum materials after both sintering methods are given in Table 1 . The PM compacts were found to have a hardness of $35 \mathrm{HB}$ hardness and a density of $2,475 \mathrm{~g} / \mathrm{cm} 3$ in a furnace at $600^{\circ} \mathrm{C}$ for 600 minutes in an argon atmosphere using a conventional method. The same hardness and density values were achieved in 4 minutes sintering time under vacuum using UHFIS. It is seen that the hardness and density values increase with the increase of the induction sintering temperature.

When the values are examined, it can be seen that at the temperature of $550-580^{\circ} \mathrm{C}$ during induction sintering, the samples are not sinterable enough and cannot form bonds. Although hardness and dense values at $610^{\circ} \mathrm{C}$ are the best results, it is seen that the eruptions occur in the sample as shown in Figure 3-c. It has therefore been determined that temperatures above $600^{\circ} \mathrm{C}$ are too high for sintering for Al PM samples. Compared with conventional sintering and induction sintering methods, the optimum sintering temperature was determined to be $600^{\circ} \mathrm{C}$. When induction and conventional sintering times are compared, it is seen that the conventional sintering time is 15 times higher.

Table 2: Energy consumption and energy cost values of aluminum samples as a result of induction and conventional sintering.

\begin{tabular}{|c|c|c|c|c|c|c|c|c|}
\hline \multirow{2}{*}{$\begin{array}{c}\text { Al PM } \\
\text { compacts }\end{array}$} & \multicolumn{5}{|c|}{$\begin{array}{c}\text { Induction Sintering } \\
\text { (4 minutes) }\end{array}$} & $\begin{array}{c}\text { Conventional } \\
\text { Sintering } \\
(\mathbf{6 0} \text { minutes) }\end{array}$ \\
\cline { 2 - 9 } & $\mathbf{5 5 0}^{\circ} \mathbf{C}$ & $\mathbf{5 6 0}^{\circ} \mathbf{C}$ & $\mathbf{5 7 0}^{\circ} \mathbf{C}$ & $\mathbf{5 8 0}^{\circ} \mathbf{C}$ & $\mathbf{5 9 0}^{\circ} \mathbf{C}$ & $\mathbf{6 0 0}^{\circ} \mathbf{C}$ & $\mathbf{6 1 0}^{\circ} \mathbf{C}$ & $\mathbf{6 0 0}^{\circ} \mathbf{C}$ \\
\hline $\begin{array}{c}\text { Energy } \\
\text { Consumption } \\
\left(\mathbf{k W h . k g}^{-1}\right)\end{array}$ & 4.987 & 5.030 & 5.087 & 5.134 & 5.227 & 5.254 & 5.324 & 2.053 \\
\hline $\begin{array}{c}\text { Cost } \\
\left(\$ . \mathbf{k g}^{-1}\right)\end{array}$ & 0.4883 & 0.4925 & 0.4981 & 0.5029 & 0.5118 & 0.5144 & 0.5212 & 0.2011 \\
\hline
\end{tabular}

Table 2 shows the energy consumption and energy cost values of Al PM samples for induction and conventional sintering processes. Sintering with induction at $600^{\circ} \mathrm{C}$ for 4 minutes resulted in a cost of $0.5144 \$ . \mathrm{kg}^{-1}$ for energy consumption of $5.254 \mathrm{Wh} . \mathrm{kg}^{-1}$. Conventional sintering at $600^{\circ} \mathrm{C}$ for 1 hour resulted in a cost of $0.2011 \$ \mathrm{Kg}^{-1}$ for energy consumption of $2.053 \mathrm{kWh} . \mathrm{kg}^{-1}$. 


\section{Conclusions}

In the work done, pure Al PM wastes were sintered UFIHS or conventionally. The results obtained are given below.

- It has been determined that the increase of the induction-induced sintering temperature increases the production cost and power.

- It has been determined that the optimum sintering temperature of $\mathrm{Al} \mathrm{PM}$ compacts by induction is $600^{\circ} \mathrm{C}$.

- Compared with the conventional sintering and induction sintering processes, Al-based PM samples were found to be sintered in 15 times shorter time using induction. When the hardness and density values are compared, the values are almost the same.

- Compared with induction and conventional sintering, it was found that the induction process cost is about 2.5 times higher than the process cost.

\section{Acknowledgment}

In this study, UHFIS was using for this resarch was ensured by Manisa Celal Bayar University BAP project and TUBITAK project (FBE 2012-022 and 214M414)

\section{References}

Amirjan, M., Khorsand, H., Siadati, M. H., and Farsani, R. E., "Artificial Neural Network prediction of $\mathrm{Cu}-\mathrm{Al}_{2} \mathrm{O}_{3}$ composite properties prepared by powder metallurgy method", Journal of Materials Research and Technology, 2(4), 351-355, 2013.

Angelo, P. C., and Subramanian, R., Powder metallurgy: science, technology and applications. PHI Learning Pvt. Ltd., 2008.

Baghani, M., Aliofkhazraei, M., and Poursalehi, R., "Microwave-assisted Sintering of Fe-Al2O3 Nanocomposites: Study of Corrosion and Wear Properties", Procedia Materials Science, 11, 689-694, 2015.

Bisht, A., Srivastava, M., Kumar, R. M., Lahiri, I., and Lahiri, D., "Strengthening mechanism in graphene nanoplatelets reinforced aluminum composite fabricated through spark plasma sintering", Materials Science and Engineering: A, 695, 20-28, 2017.

Caliman, L. B., Bichaud, E., Soudant, P., Gouvea, D., and Steil, M. C., "A simple flash sintering setup under applied mechanical stress and controlled atmosphere", MethodsX, 2, 392-398, 2015.Cooke, R. W., Kraus, N. P., and Bishop, D. P., "Spark plasma sintering of aluminum powders prealloyed with scandium additions", Materials Science and Engineering: A, 657, 71-81, 2016.

Cavdar, P. S., and Cavdar, U., "The evaluation of different environments in ultra-high frequency induction sintered powder metal compacts”, Revista de Metalurgia, 51(1), e036, 2015.

Çavdar, U., and Atik, E., "Investigation of conventional-and induction-sintered iron and iron-based powder metal compacts", JOM, 66(6), 1027-1034, 2014.

Çavdar, U., and Gulsahin, I., "Ultra high frequency induction welding of powder metal compacts", Revista de Metalurgia, 50(2), 2014.

Çavdar, U., and Kusoglu, İ. M., "Effects of coil design on induction welding of sintered iron based compacts", Materials Testing, 56(11-12), 973-979, 2014.

Çavdar, U., "Mechanical properties of hot forged ANSI 1050 steel”, Materials Testing, 56(3), 208-212, 2014.

Durowoju, M. O., Sadiku, E. R., Diouf, S., Shongwe, M. B., and Olubambi, P. A., "Spark plasma sintering of graphite-aluminum powder reinforced with SiC/Si particles", Powder Technology, 284, 504-513, 2015. 
Dutel, G. D., Langlois, P., Tingaud, D., Vrel, D., and Dirras, G., "Data on the influence of cold isostatic pre-compaction on mechanical properties of polycrystalline nickel sintered using Spark Plasma Sintering”, Data in Brief, 11, 61-67, 2017.

Firestein, K. L., Corthay, S., Steinman, A. E., Matveev, A. T., Kovalskii, A. M., Sukhorukova, I. V., ... and Shtansky, D. V., "High-strength aluminum-based composites reinforced with BN, AlB 2 and AlN particles fabricated via reactive spark plasma sintering of Al-BN powder mixtures", Materials Science and Engineering: A, 681, 1-9, 2017.

Ghasali, E., Pakseresht, A. H., Alizadeh, M., Shirvanimoghaddam, K., and Ebadzadeh, T., "Vanadium carbide reinforced aluminum matrix composite prepared by conventional, microwave and spark plasma sintering", Journal of Alloys and Compounds, 688, 527-533, 2016.

Gökozan, H., Taştan, M., Taşkin, S., Çavdar, P., and Çavdar, U., “Comparative Energy Consumption Analyses Of an Ultra High Frequency Induction Heating System For Induction Heating, Welding and Sintering Applications" Materials testing, 58, 1009$1013,2016$.

Guo, B., Ni, S., Yi, J., Shen, R., Tang, Z., Du, Y., and Song, M., "Microstructures and mechanical properties of carbon nanotubes reinforced pure aluminum composites synthesized by spark plasma sintering and hot Rolling", Materials Science and Engineering: A, 698, 282-288, 2017

Kang, S. J. L. Sintering: densification, grain growth and microstructure. Butterworth-Heinemann, 2004.

Lemke, F., Rheinheimer, W., and Hoffmann, M. J., “A comparison of power controlled flash sintering and conventional sintering of strontium titanate”, Scripta Materialia, 130, 187-190, 2017.

Mackie, A. J., Hatton, G. D., Hamilton, H. G., Dean, J. S., and Goodall, R., "Carbon uptake and distribution in spark plasma sintering (SPS) processed Sm (Co, Fe, Cu, Zr)", Materials Letters, 171, 14-17, 2016.

Özdemir, A., and Taştan, M., "PLL based digital adaptive filter for detecting interharmonics", Mathematical Problems in Engineering, 1-10, 2014.

Pozzoli, V. A., Ruiz, M. S., Kingston, D., and Razzitte, A. C., "Entropy Production during the Process of Sintering", Procedia Materials Science, 8, 1073-1078, 2015.

Reddy, M. P., Ubaid, F., Shakoor, R. A., Mohamed, A. M. A., and Madhuri, W., "Structural and mechanical properties of microwave sintered Al Ni 50 Ti 50 composites", Journal of Science: Advanced Materials and Devices, 1(3), 362-366, 2016.

Sedlak, J., Rican, D., Piska, M., and Rozkosny, L., "Study of Materials Produced by Powder Metallurgy Using Classical and Modern Additive Laser Technology", Procedia Engineering, 100, 1232-1241, 2015.

Sharma, P., and Majumdar, J. D., "Studies on nano-crystalline CoNiCrAlY consolidated by conventional and microwave sintering", Advanced Powder Technology, 27(1), 72-84, 2016.

Sweet, G. A., Brochu, M., Hexemer, R. L., Donaldson, I. W., and Bishop, D. P., "Microstructure and mechanical properties of air atomized aluminum powder consolidated via spark plasma sintering", Materials Science and Engineering: A, 608, 273-282, 2014.

Taskin, S., and Gokozan, H., "Determination of the spectral properties and harmonic levels for driving an induction motor by an inverter driver under the different load conditions", Elektronika ir Elektrotechnika, 108(2), 75-80, 2011.

Tastan, M., Gokozan, H., Taskin, S., and Çavdar, U., "Comparative energy consumption analyses of an ultra high frequency induction heating system for material processing applications”, Revista de Metalurgia, 51(3), 2015. 
Wudy, K., Lanzl, L., and Drummer, D., "Selective Laser Sintering of Filled Polymer Systems: Bulk Properties and Laser Beam Material Interaction”, Physics Procedia, 83, 991-1002, 2016.

Xun, W., Jie, Z., and Qiang, L., "Multi-objective optimization of medium frequency induction heating process for large diameter pipe bending", Procedia Engineering, 81, 2255-2260, 2014.

Yasa, E., Poyraz, O., Solakoglu, E. U., Akbulut, G., and Oren, S., "A Study on the Stair Stepping Effect in Direct Metal Laser Sintering of a Nickel-based Superalloy", Procedia CIRP, 45, 175-178, 2016. 